\title{
Coccolithophore species as indicators of surface oceanographic conditions in the vicinity of Azores islands
}

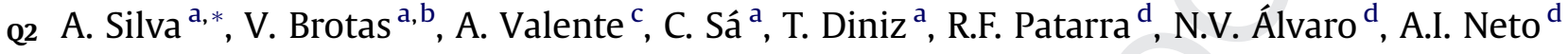 \\ ${ }^{a}$ Centro de Oceanografia, Faculdade de Ciências da Universidade de Lisboa, Campo Grande, 1749-016 Lisboa, Portugal \\ ${ }^{\mathrm{b}}$ Plymouth Marine Laboratory, Prospect Place, Plymouth PL1 3DH, United Kingdom

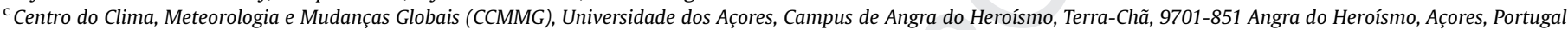

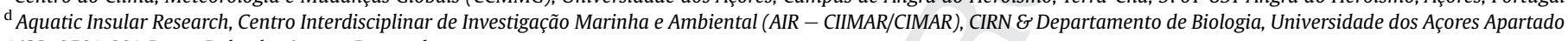 \\ 1422, 9501-801 Ponta Delgada, Açores, Portugal
}

\section{A R T I C L E I N F O}

\section{Article history:}

Received 14 March 2012

Accepted 28 December 2012

Available online $\mathrm{xxx}$

\section{Keywords:}

coccolithophores

phytoplankton

HPLC pigments

Azores archipelago

Atlantic Ocean

\begin{abstract}
A B S T R A C T
During summer 2008 and spring 2009, surface oceanographic surveys were carried out around three islands of the Azores archipelago (Terceira, São Miguel and Santa Maria) to assess the phytoplankton distribution and associated physico-chemical processes. The Azores archipelago is a major feature in the biogeochemical North Atlantic Subtropical Gyre (NAST) province although its influence on the productivity of the surrounding ocean is poorly known. Surface phytoplankton was studied by microscopy and HPLC (High Precision Liquid Chromatography). The mean values for biomass proxy Chlorophyll $a$ (Chla) ranged from 0.04 to $0.55 \mu \mathrm{g} \mathrm{L}{ }^{-1}$ (Chla maximum $=0.86 \mu \mathrm{g} \mathrm{L}{ }^{-1}$ ) and coccolithophores were the most abundant group, followed by small flagellates, Cyanobacteria, diatoms and dinoflagellates being the least abundant group. The distribution of phytoplankton and coccolithophore species in particular presented seasonal differences and was consistent with the nearshore influence of warm subtropical waters from the south Azores current and colder subpolar waters from the north. The satellite-derived circulation patterns showed southward cold water intrusions off Terceira and northward warm water intrusions off Santa Maria. The warmer waters signal was confirmed by the subtropical coccolithophore assemblage, being Discosphaera tubifera a constant presence under these conditions. The regions of enhanced biomass, either resulting from northern cooler waters or from island induced processes, were characterized by the presence of Emiliania huxleyi. Diatoms and dinoflagellates indicated coastal and regional processes of nutrient enrichment and areas of physical stability, respectively.
\end{abstract}

() 2013 Elsevier Ltd. All rights reserved.

\section{Introduction}

The Azores archipelago $\left(36^{\circ}-39^{\prime} \mathrm{N}, 25^{\circ}-31^{\prime} \mathrm{W}\right)$ consists of nine volcanic islands forming three groups (western, central and eastern) located within the North Atlantic Subtropical Gyre biogeochemical province (NAST; Longhurst et al., 1995). The archipelago lies in a transition zone between the North Atlantic Current (NAC) to the northwest, the Azores Current (AC), a jet-like current, ca. $34^{\circ} \mathrm{N}$, to the south, and a region of weak circulation to the northeast (Juliano and Alves, 2007). Related to the main jet of the Azores Current there is an important thermohaline front, separating fresher and colder waters to the north and warmer and saltier water masses to the south (Gould, 1985). The islands are not in the direct eastward path of the main jet, but are affected by the recirculation patterns and eddies that originate from its

\footnotetext{
* Corresponding author.

E-mail addresses: asilva@fc.ul.pt, amsilva@ipma.pt, adsilva@fc.ul.pt (A. Silva).
}

meandering. Due to convergent southward and northward flows from the NAC and AC, respectively, strong thermal gradients are typical of the region (Lafon et al., 2004). Topographically-induced turbulence significantly modifies the physical and biological conditions adjacent to islands, which often result in higher marine productivity (Bakker et al., 2007; Hasegawa et al., 2008). In the NAST province, wintertime mixing provides the seasonal replenishment of nutrients to the euphotic zone while in spring, thermal stratification favours phytoplankton growth, which progressively leads to surface nutrient depletion by late summer. In the North Atlantic, blooms and seasonal mass flux of coccolithophores are known to occur (Holligan et al., 1993; Broerse et al., 2000; Sprengel et al., 2000) and most of the annual production takes place during spring (Schiebel et al., 2011).

Coccolithophores are a calcareous nannoplanktonic group which widespread distribution in the ocean, range from oligotrophic subtropical gyres to temperate and high latitude eutrophic regimes. 
The importance and motivation for studying coccolithophore dynamics, is that according to particular environmental conditions characteristic assemblages are found, which can be distinguished by their coccolith types and coccosphere morphology. As the group is known to be driven by oceanographic changes, reflecting on a fine scale, ecological patterns, and may be sensitive to climate change and ocean acidification (Broerse et al., 2000; Tortell et al., 2002; Rost et al., 2003; Smyth et al., 2004; Andruleit, 2007; Silva et al., 2008; Tyrrell, 2008) it is always relevant to gather ecological information on individual species to determine which are capable of providing key significant responses. In this sense, Emiliania huxleyi is probably one of the best-studied phytoplankton species that is of relevance in the ocean. It is the most predominant coccolithophore and blooms have been reported from different settings of the North Atlantic and Pacific (Beaufort and Heussner, 2001; Beaufort et al., 2008), under conditions of high turbulence, during an early stage of the phytoplankton succession in spring, as well as during calm and stratified conditions following the spring bloom. i.e., during May-July in the North Atlantic (Silva et al., 2008, 2009; Schiebel et al., 2011). On the other hand, in warm waters depleted in nitrate and under very high light intensities, as off Bermuda (N Atlantic) the coccolithophore assemblage is different and species such as Discosphaera tubifera are observed (Haidar and Thierstein, 2001).

The present work is an output of project CAMAG, characterization of coastal water masses in the vicinity of the islands of Terceira (Central group), São Miguel and Santa Maria (Oriental group). Our aim is to assess the abundance and diversity of the phytoplankton assemblage and describe the major physical patterns and regional processes by using coccolithophores as indicators of surface oceanographic changes and seasonal variations.

\section{Methods}

\subsection{Surveyed area and sampling strategy}

During summer 2008 (July-August) and spring 2009 (MayJune) three surveys were carried out, covering three islands of the Azores archipelago, Terceira (TER, Central group), São Miguel (SM,
Oriental group) and Santa Maria (SMA, Oriental group) (Fig. 1). As sampling was defined in the context of CAMAG project (related to the European Water Framework Directive), 44 samples were collected on board a small vessel, using a Niskin bottle to collect the surface water layer for phytoplankton microscopy observation and cell counting, pigment analysis and nutrient concentrations. Details on the water samples processing for the different analysis are described below. During summer, five stations were sampled around Terceira (stations 1,4 and 5 in the south; station 3 in the north and station 2 in the east), eleven around São Miguel (stations 1-5 and station $G$ in the south and stations 6-10 in the north) and two in Santa Maria (station 1 and 2, in the south and east, respectively). During spring, four additional sites were sampled around Terceira (stations I1, P1 and P2 in the south and station I2 in the east), and two both in São Miguel (stations IN in the north and IS in the south) and Santa Maria (stations I1 and I2 in the south and east, respectively) (Fig. 3). Most of the stations were near the coast with $40 \mathrm{~m}$ depth, some stations were at ca.100 m depths (I1 at Terceira and IN and IS at São Miguel, I1 and I2 at Santa Maria) and a few at depths greater than $200 \mathrm{~m}$ (G at São Miguel, P1 and P2 at Terceira).

\subsection{Physico-chemical parameters}

Surface temperature was determined in situ with a Multiparameter Water Quality Portable Meter Hanna HI-9828. Water for nutrient determination was filtered through a $0.45 \mu \mathrm{m}$ Millipore filter and stored at $-4{ }^{\circ} \mathrm{C}$ for subsequent colorimetric analyses with a Tecator FIAstar ${ }^{\mathrm{TM}} 5000$ Analyser. Nitrite $\left(\mathrm{NO}_{2}^{-}\right)$plus nitrate $\left(\mathrm{NO}_{3}^{-}\right)$ were determined according to Grassoff (1976), phosphate $\left(\mathrm{PO}_{4}^{3^{-}}\right)$ was determined according to Murphy and Riley (1962) and silicate $\left(\mathrm{Si}(\mathrm{OH})_{4}\right)$ according to Fanning and Pilson (1973). The detection limit for seawater analysis was $0.5 \mu \mathrm{M}$ for silicate, $0.11 \mu \mathrm{M}$ for nitrite + nitrate and $0.1 \mu \mathrm{M}$ for phosphate.

\subsection{Phytoplankton analysis}

The phytoplankton assemblage was identified and counted through microscopy (Section 2.3.1) and photosynthetic pigments

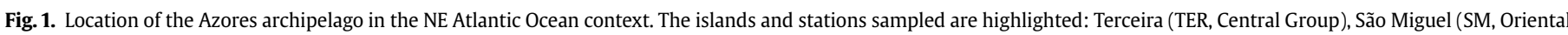
Group) and Santa Maria (SMA, Oriental Group). 

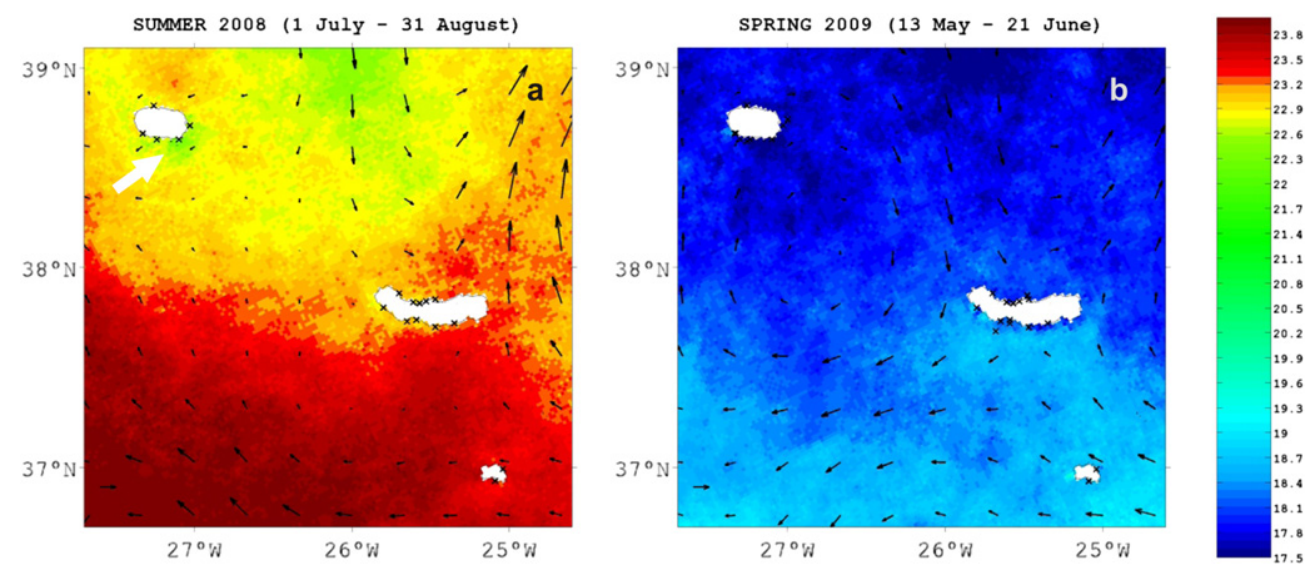

Fig. 2. Satellite-derived SST and surface geostrophic currents averaged: a) during the 2008 observation period ( 1 July-31 August 2008); and b) during the 2009 observation period (13 May-21 June 2009). Stations are represented by crosses. White arrow point to coastal feature. In the lower left corner of each figure is represented a horizontal reference vector for a current speed of $10 \mathrm{~cm} / \mathrm{s}$.

were biochemically quantified by HPLC (Section 2.3.2). These complementary methodologies were fundamental to quantitatively evaluate and characterize the phytoplankton community, in particular the smaller size fraction, known to be present in oceanic waters and normally underestimated by microscopy. A Principal Component Analysis (Section 2.3.3) was used to statistically highlight potential groups of species regarding their temporal and horizontal distribution in all stations around the three islands.

\subsubsection{Microscopy analysis}

Phytoplankton samples were preserved with hexamethylenetetramine buffered formalin to a final concentration of $2 \%$ (Throndsen, 1978). Phytoplankton species were identified and enumerated in subsamples of $50 \mathrm{ml}$ by the Utermöhl technique (Hasle, 1978), using a Zeiss IM35 inverted microscope with phase contrast and bright field illumination. A magnification of $160 \times$ and $400 \times$ was used to analyse the phytoplankton assemblage with a detection limit of 60 cells $\mathrm{L}^{-1}$ and 3000 cells $\mathrm{L}^{-1}$, respectively at a $95 \%$ confidence level (Bollmann et al., 2002). When possible, the cells were identified to species level according to Hasle and Syvertsen (1996), Dodge (1982) and Young et al. (2003). A scanning electron microscope (JEOL-5200) was used to complete the identifications, in particular for the nannoplanktonic coccolithophores (e.g. holococcolithophores). Cells recognized as coccolithophores but that could not be further identified were included in the category "Undetermined species". In addition, it was not possible to identify several small phytoplankton cells, which are designated hereafter as small flagellates/others.

\subsubsection{HPLC pigment analysis}

The biomass and composition of phytoplankton were biochemically determined by HPLC, i.e, through the identification and quantification of various pigments and carotenoids from the different classes of microalgae. Water samples (1.5 L) were filtered

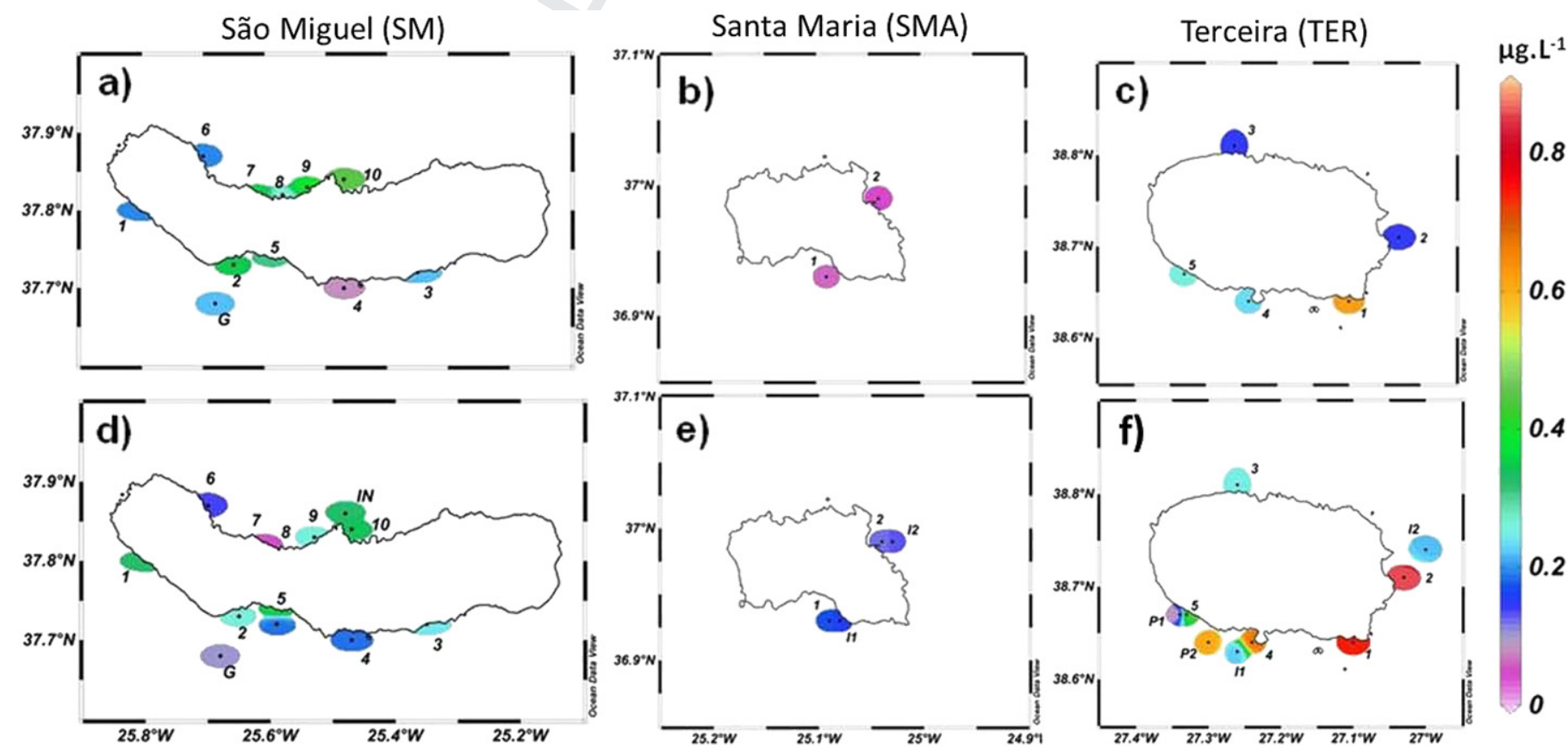

Fig. 3. Distribution of Chla ( $\mu \mathrm{g} \mathrm{L}^{-1}$ ) in São Miguel, Santa Maria and Terceira (from left to right), during summer 2008 (a,b and c) and spring 2009 (d,e and f). 
onto Whatman GF/F filters (nominal pore size of $0.7 \mu \mathrm{m}$ and $25 \mathrm{~mm}$ diameter), under vacuum pressure lower than 500 mbar. The filters were immediately frozen and stored at $-80^{\circ} \mathrm{C}$. Phytoplankton pigments were extracted with $3 \mathrm{~mL}$ of $95 \%$ cold-buffered methanol ( $2 \%$ ammonium acetate) for $30 \mathrm{~min}$ at $-20{ }^{\circ} \mathrm{C}$, in the dark. Samples were sonicated (Bransonic, model 1210, w: 80, Hz: 47) for $1 \mathrm{~min}$ at the beginning of the extraction period. The samples were then centrifuged at $1100 \mathrm{~g}$ for $15 \mathrm{~min}$, at $4{ }^{\circ} \mathrm{C}$. Extracts were filtered (Fluoropore PTFE filter membranes, $0.2 \mu \mathrm{m}$ in pore size) and immediately injected into the HPLC. Pigment extracts were analysed using a Shimadzu HPLC comprised of a solvent delivery module (LC-10ADVP) with system controller (SCL-10AVP), a photodiode array (SPD-M10ADVP), and a fluorescence detector (RF10AXL). Chromatographic separation was carried out using a C18 column for reverse phase chromatography (Supelcosil; $25 \mathrm{~cm}$ long; $4.6 \mathrm{~mm}$ in diameter; $5 \mathrm{~mm}$ particles) and a $35 \mathrm{~min}$ elution programme. The solvent gradient followed Kraay et al. (1992) adapted by Brotas and Plante-Cuny (1996) with a flow rate of $0.6 \mathrm{~mL} \mathrm{~min}{ }^{-1}$ and an injection volume of $100 \mu \mathrm{L}$. The limit of detection (LOD) and limit of quantification (LOQ) of this method were calculated and discussed in Mendes et al. (2007). Pigments were identified from absorbance spectra plus retention times and concentrations calculated from the signals in the photodiode array detector (Ex. $430 \mathrm{~nm}$; Em. $670 \mathrm{~nm}$ ). Calibration of the HPLC peaks was performed using commercial standards, namely, chlorophyll $a$ (Chla) and chlorophyll $b$ from Sigma, chlorophyll $c_{2}$, chlorophyll $c_{3}$, peridinin, fucoxanthin, diadinoxanthin, diatoxanthin, 19'-hexanoyloxyfucoxanthin, neoxanthin, prasinoxanthin, violaxanthin, alloxanthin, 19'butanoyloxyfucoxanthin and zeaxanthin from DHI (Institute for Water and Environment, Denmark).

Some pigments are exclusive of specific phytoplankton groups and can be used as taxonomic indicators (Jeffrey et al., 1997). For example, 19'-Hexanoyloxyfucoxanthin (Hex-fuco) is exclusive of Prymnesiophytes and was used in this study as an indicator of coccolitophores. Coccolithophores cell counts were positively correlated with Hex-fuco $\left(r^{2}=0.369, p<0.05\right)$, but not with fucoxanthin (also present in coccolithophores). Whereas fucoxanthin presented a significant correlation with diatoms cell counts $\left(r^{2}=0.535, p<0.001\right)$. Fucoxanthin was therefore used as a proxy for diatoms. Peridin is exclusive to dinoflagellates and was used as their marker, however the inverse is not necessarily the case (Jeffrey et al., 1997). The presence of this group was not always coincident with peridin concentration meaning that some dinoflagellates species found lacked this pigment or had the pigment in concentrations lower than the HPLC detection limit. Alloxanthin (biomarker for cryptophytes), prasinoxantin (exclusive for prasinophytes), chlorophyll $b$ (present in clorophytes, prasinophytes and euglenophytes) and 19'-Butanoyloxyfucoxanthin (in crysophytes and prymnesiophytes) were used as a proxy for flagellates while zeaxanthin (in clorophytes and cyanobacteria) was used as prokaryotes indicator. This decision was based on the observation that the source of zeaxanthin presented a distinct temporal and spatial distribution from the other three pigments, being most probably of cyanobacteria. Unicellular marine cyanobacteria belong mainly to two genera, Synechococcus and Prochlorococcus, which differ in the form of chlorophyll $a$, monovinyl and divinyl, respectively. The HPLC method used does not allow the separation of these pigments and therefore were treated as a group, prokaryotes.

\subsubsection{Principal component analysis}

Principal component analysis (PCA; Hair et al., 1998) was conducted in order to identify potential groups of species regarding their temporal and spatial distribution in all stations around the three islands of Azores, during summer and spring (after data standardization and $\log +1$ transformation) using Primer 6 software (Clarke and Gorley, 2006). The input variables for the PCA were cell counts, pigment concentrations and stations (separated by seasons). The analysis was carried out with the species that occurred at least in 20\% of the samples. PCA axis labels (PC1 associated with seasonality and PC2 with nutrient availability) derived from the interpretation of overall results.

\subsection{Satellite derived data}

Satellite-derived maps of sea surface temperature (SST) and surface currents were used to investigate oceanographic conditions in the region. The SST maps were obtained from the "North Atlantic Regional Sea Surface Temperature" (NAR SST) product, provided by the EUMETSAT's Ocean and Sea Ice Satellite Application Facility (OSI-SAF; CMS, 2009). The NAR SST product consists of four daily SST maps (approximately $02 \mathrm{~h}, 10 \mathrm{~h}, 12 \mathrm{~h}$ and $20 \mathrm{~h}$ UTC) calculated from the infra-red (IR) channels of the National Oceanic and Atmospheric Administration/Advanced Very High Resolution Radiometer (NOAA/AVHRR) sensors and re-mapped onto a stereopolar grid at $2 \mathrm{~km}$ resolution. Geostrophic velocity fields were derived from the delayed time "Up-to-date" global gridded product of sea level anomalies and produced by Ssalto/Duacs at Collecte Localization Satellites (CLS, 2009). This product is generated every 7 days at $1 / 3^{\circ}$ resolution and was obtained from the AVISO website (http:// www.aviso.oceanobs.com/en/data.html). The mean maps of SST and surface currents were computed by averaging all data between 1 July - 31 August 2008 (Fig. 2a) and 13 May - 21 June 2009 (Fig. 2b), which correspond to the first and last day of the summer and spring observation periods, respectively.

\section{Results}

\subsection{Physico-chemical data}

In situ surface temperatures from summer 2008 ranged from $17^{\circ}$ to $18.5^{\circ} \mathrm{C}$, and were on average $\sim 3{ }^{\circ} \mathrm{C}$ higher than in spring 2009 $\left(>20^{\circ} \mathrm{C}\right.$ ) (Table 1$)$. The averaged surface circulation denoted the
Table 1

Average values for temperature $\left({ }^{\circ} \mathrm{C}\right.$ ) and nutrients (Nitrite + Nitrate, Silicate and Phosphate, $\mu \mathrm{M}$ ), during summer 2008 and spring 2009 surveys, in the three islands (N-north, S-South and E-east), (-) means not measured.

\begin{tabular}{|c|c|c|c|c|c|c|c|c|c|c|c|c|c|c|}
\hline & \multicolumn{4}{|c|}{ São Miguel (SM, Oriental group) } & \multicolumn{4}{|c|}{ Santa Maria (SMA, Oriental group) } & \multicolumn{6}{|c|}{ Terceira (T, Central group) } \\
\hline & \multicolumn{2}{|c|}{ Summer 08} & \multicolumn{2}{|c|}{ Spring 09} & \multicolumn{2}{|c|}{ Summer 08} & \multicolumn{2}{|c|}{ Spring 09} & \multicolumn{3}{|c|}{ Summer 08} & \multicolumn{3}{|c|}{ Spring 09} \\
\hline & $\mathrm{N}$ & $\mathrm{S}$ & $\mathrm{N}$ & $\mathrm{s}$ & $\mathrm{S}$ & E & $\mathrm{s}$ & E & $\mathrm{N}$ & $\mathrm{S}$ & E & $\mathrm{N}$ & $\mathrm{S}$ & E \\
\hline Temperature ( $\underline{o} \mathrm{C})$ & 21.9 & 21.4 & 18.5 & 18.3 & - & - & 18.5 & 18.1 & 22.6 & 20.4 & 22.0 & 17.6 & 17.0 & 17.4 \\
\hline Silicates $(\mu \mathrm{M})$ & - & 12.90 & 6.83 & 7.32 & - & - & 6.41 & 9.90 & 5.77 & 6.11 & 14.48 & 6.54 & 11.40 & 8.92 \\
\hline Phosphates $(\mu \mathrm{M})$ & 0.24 & 0.27 & 0.66 & 0.58 & - & - & 0.74 & 0.66 & 0.21 & 0.20 & 0.22 & 0.94 & 0.86 & 0.85 \\
\hline Number of stations & 5 & 6 & 6 & 7 & 1 & 1 & 2 & 2 & 1 & 3 & 1 & 1 & 6 & 2 \\
\hline
\end{tabular}


influence of the Azores Current on the southernmost islands, and the analysis of averaged SST maps during the sampling periods revealed patches of colder waters in the vicinity of the islands, more visible at the S-SW Terceira (highlighted by a white arrow in Fig. 2a). The sum of surface nitrate plus nitrite, mostly determined during spring recorded the higher concentrations in Terceira and São Miguel (Table 1). Phosphate concentrations, when determined during both seasons, were higher during spring and around Terceira. Silicate was always largely available particularly at the S-SE sides of the islands, being the higher concentrations determined during summer south of São Miguel and at the east side of Terceira (Table 1 ). The spring concentrations of silicate were at least three times higher than those recorded during summer.

\subsection{Phytoplankton assemblage}

Phytoplankton biomass, given by its proxy, Chla concentration, ranged in average between $0.04 \mu \mathrm{g} \mathrm{L}^{-1}$ at the east side of Santa Maria, during summer and $0.55 \mu \mathrm{g} \mathrm{L}^{-1}$ at the eastern stations of Terceira, during spring, where the maximum was recorded $\left(0.86 \mu \mathrm{g} \mathrm{L}^{-1}\right.$ in \# 2 at east Terceira, Fig. 3 f).

Coccolithophores, diatoms and dinoflagellates were usually the dominant groups, accounting for $90 \%$ of total counted phytoplankton (TF) (Fig. 4, Table 2). The highest abundances (cells $\mathrm{L}^{-1}$ ) were observed during spring while during summer the number of species identified was higher. Coccolithophores overall presented the greatest abundances, reaching a maximum of $93 \%$ of total phytoplankton counted in Santa Maria, during spring and a minimum of $1 \%$ in Terceira, during summer, when the assemblage was dominated by dinoflagellates and small flagellates (Table 2). Dinoflagellates were most abundant during summer while diatoms increased during spring.

The analysis of chromatograms identified a total of 16 pigments (Table 2). Overall, the pigment signatures obtained by HPLC confirmed the distinct cell distribution patterns identified by microscopy but revealed also the presence of a prokaryotes-picoplankton community, unable to be identified by microscopy (Table 2). Although almost no zeaxantin was observed in spring, this pigment had, in average, relatively high concentrations in summer $\left(0.07 \mu \mathrm{g} \mathrm{L}^{-1}\right)$, particularly in Terceira and at the southernmost island of Santa Maria (Oriental group), indicating that the prokaryotes community could be significant and probably dominant in this area, during this period, concomitantly with the lowest totalcell and Chla values $\left(0.04 \mu \mathrm{g} \mathrm{L}^{-1}\right)$.

The most diversified pigment's set was found in the northern stations of São Miguel, during summer, confirming the microscopy observations of euglenophyceae cells and small flagellates, and allowing a further resolution within the small flagellates' assemblage. This community seems to be constituted by cryptophytes (biomarker alloxanthin), prasinophytes, or prasinophytes plus chlorophytes (as prasinoxanthin, Chlb, violaxanthin and neoxanthin were detected), and probably chrysophytes (its presence, however, cannot be confirmed, as Chlc3, diadinoxanthin, fucoxanthin and 19'ButFuco, can be present also in other groups identified by microscopy as coccolitophores and diatoms). The most abundant carotenoid was fucoxanthin, especially in Terceira

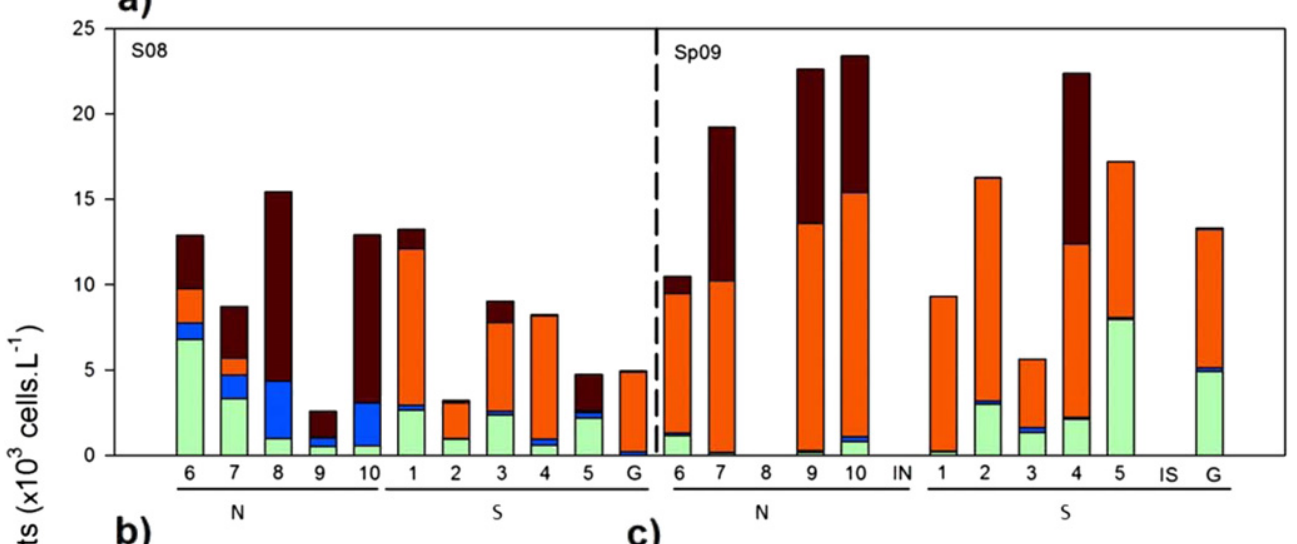

b)

c)

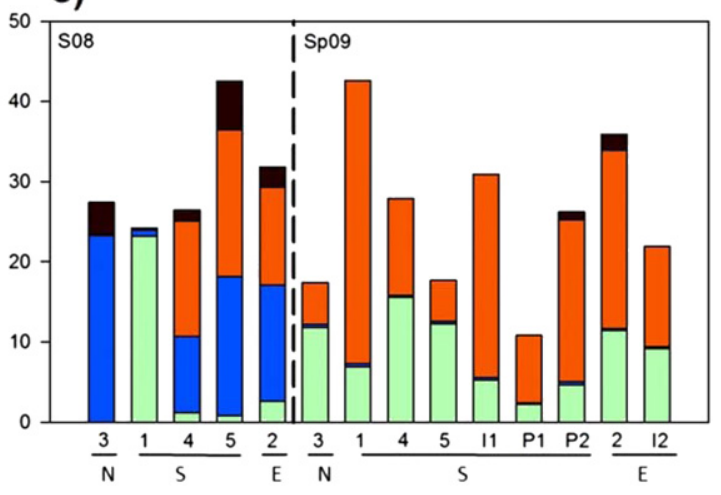

Stations

Diatoms

Dinoflagellates

Coccolithophores

Others

Fig. 4. Microscopy observations of phytoplankton groups $\left(\times 10^{3}\right.$ cells L $\left.^{-1}\right)$ in a) São Miguel, b) Santa Maria and c) Terceira. [N-north, S-south, E-east, S08-summer 2008 and Sp09spring 2009]. Note scales are different. 
Table 2

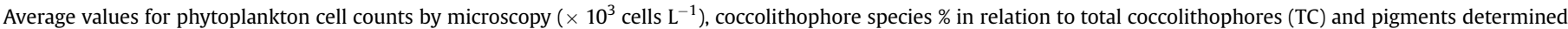
( $\mu \mathrm{g} \mathrm{L}^{-1}$ ) during summer 2008 and spring 2009 surveys, by geographical location (N-north, S-South and E-east) per island. (-) means not measured.

\begin{tabular}{|c|c|c|c|c|c|c|c|c|c|c|c|c|c|c|}
\hline \multirow[t]{3}{*}{$(\times 103$ cells $\mathrm{L}-1)$} & \multicolumn{4}{|c|}{ São Miguel (SM, Oriental group) } & \multicolumn{4}{|c|}{ Santa Maria (SMA, Oriental group) } & \multicolumn{6}{|c|}{ Terceira (T, Central group) } \\
\hline & \multicolumn{2}{|c|}{ Summer 08} & \multicolumn{2}{|c|}{ Spring 09} & \multicolumn{2}{|c|}{ Summer 08} & \multicolumn{2}{|c|}{ Spring 09} & \multicolumn{3}{|c|}{ Summer 08} & \multicolumn{3}{|c|}{ Spring 09} \\
\hline & $\mathrm{N}$ & $\mathrm{S}$ & $\mathrm{N}$ & $\mathrm{S}$ & $\mathrm{S}$ & $\mathrm{E}$ & $\mathrm{S}$ & $\mathrm{E}$ & $\mathrm{N}$ & $\mathrm{S}$ & $\mathrm{E}$ & $\mathrm{N}$ & $\mathrm{S}$ & $\mathrm{E}$ \\
\hline Total phytoplankton (TF) & 10.5 & 7.2 & 18.9 & 14.0 & 5.0 & 3.9 & 8.5 & 4.5 & 27.4 & 31.0 & 31.8 & 17.4 & 26.0 & 28.9 \\
\hline Coccolithophores (TC) & 0.6 & 4.7 & 11.5 & 8.9 & 4.3 & 3.3 & 6.9 & 4.2 & 0.2 & 11.0 & 12.2 & 5.2 & 17.7 & 17.3 \\
\hline Coccolithophores (\% TF) & 6 & 65 & 61 & 64 & 86 & 85 & 81 & 93 & 1 & 35 & 38 & 30 & 68 & 60 \\
\hline Diatoms & 2.4 & 1.5 & 0.6 & 3.3 & 0.1 & 0.1 & 1.1 & 0.3 & 0.1 & 8.4 & 2.6 & 11.9 & 7.8 & 10.3 \\
\hline Dinoflagellates & 1.7 & 0.2 & 0.1 & 0.2 & 0.6 & 0.4 & 0 & 0 & 23.2 & 9.0 & 14.5 & 0.3 & 0.3 & 0.3 \\
\hline $\begin{array}{l}\text { Chryptophyta }+ \text { Prasinophyta }+ \\
\text { small flagellates }+ \\
\text { Cyanobacteria }\end{array}$ & 5.7 & 0.8 & 6.8 & 1.7 & 0.0 & 0.1 & 0.5 & 0.0 & 4.0 & 4.0 & 2.5 & 0.0 & 0.2 & 1.0 \\
\hline Number of species identified & 27 & 29 & 19 & 20 & 24 & 16 & 19 & 12 & 27 & 30 & 34 & 32 & 28 & 28 \\
\hline Number of stations & 5 & 6 & 6 & 7 & 1 & 1 & 2 & 2 & 1 & 3 & 1 & 1 & 6 & 2 \\
\hline \multicolumn{15}{|l|}{ (\%TC) } \\
\hline C.leptoporus & - & 0.5 & 0.5 & 0.1 & 1.4 & - & 0.4 & - & 13.3 & 0.1 & 0.3 & - & 0.2 & 0.3 \\
\hline C.quadriperforatus & - & 0.2 & - & - & - & - & - & 0.7 & - & 0.1 & - & 0.4 & 0.5 & 0.7 \\
\hline D.tubifera & - & 1.0 & 0.2 & 0.1 & 9.8 & 12.1 & 1.1 & 1.2 & 46.7 & 0.5 & 0.2 & - & - & - \\
\hline E.huxleyi & 97.1 & 66.7 & 98.0 & 89.6 & - & - & 87.5 & 83.9 & - & 97.1 & 73.8 & 96.7 & 60.7 & 98.1 \\
\hline H.carteri & - & 0.2 & - & - & - & - & - & - & - & - & - & - & - & 0.1 \\
\hline Ophiaster sp. & - & 0.2 & 0.1 & - & 2.1 & 1.8 & 0.1 & 0.1 & - & - & - & - & - & - \\
\hline U.sibogae & - & 0.6 & 0.1 & 0.2 & - & - & 0.2 & 0.5 & - & - & - & 0.6 & 0.1 & 0.1 \\
\hline Syracosphaera spp. & - & 4.0 & 0.2 & 0.2 & 3.3 & 8.2 & 0.4 & 0.6 & - & - & - & 1.0 & 0.1 & 0.3 \\
\hline Holococcolithophore spp. & 2.3 & 4.9 & 1.0 & 2.0 & 83.0 & 17.5 & 10.1 & 13.0 & 26.7 & 2.1 & 1.1 & 1.4 & 38.3 & 0.4 \\
\hline Undetermined species & 0.6 & 21.7 & - & 7.9 & 0.5 & 60.4 & 0.2 & - & 13.3 & 0.1 & 24.6 & - & - & - \\
\hline \multicolumn{15}{|l|}{ Pigments ( $\left.\mu \mathrm{g} \mathrm{L}^{-1}\right)$ (maximum) } \\
\hline Chlorophyll $a(0.86)$ & 0.33 & 0.27 & 0.23 & 0.27 & 0.07 & 0.04 & 0.16 & 0.12 & 0.14 & 0.37 & 0.15 & 0.25 & 0.40 & 0.55 \\
\hline Chlorophyll $b$ (0.11) & 0.09 & 0.03 & 0.05 & 0.03 & - & - & 0.01 & - & - & 0.02 & - & - & 0.02 & 0.03 \\
\hline Fucoxanthin (0.34) & 0.04 & 0.09 & 0.02 & 0.08 & - & - & 0.06 & 0.05 & - & 0.15 & 0.03 & 0.07 & 0.18 & 0.22 \\
\hline Peridinin $(0.14)$ & 0.04 & - & - & - & - & - & - & - & 0.03 & 0.01 & 0.02 & 0.14 & 0.01 & - \\
\hline $\begin{array}{l}\text { 19'-Hexanoyloxyfucoxanthin } \\
\text { (0.15) }\end{array}$ & 0.03 & 0.03 & 0.04 & 0.05 & 0.01 & 0.01 & 0.01 & 0.03 & 0.02 & 0.05 & 0.02 & 0.03 & 0.07 & 0.10 \\
\hline $\begin{array}{l}19^{\prime} \text {-Butanoyloxyfucoxanthin } \\
\quad(0.06)\end{array}$ & 0.01 & 0.01 & - & 0.02 & - & - & 0.01 & 0.01 & - & 0.01 & - & 0.02 & 0.03 & 0.04 \\
\hline Alloxanthin (0.02) & 0.01 & - & 0.01 & - & - & - & - & - & - & - & - & - & - & - \\
\hline Zeaxanthin (0.08) & 0.06 & 0.04 & - & 0.01 & 0.06 & 0.07 & - & - & 0.06 & 0.04 & 0.07 & - & - & - \\
\hline Prasinoxanthin (0.03) & 0.01 & - & 0.01 & 0.01 & - & - & - & - & - & - & - & - & - & - \\
\hline
\end{tabular}

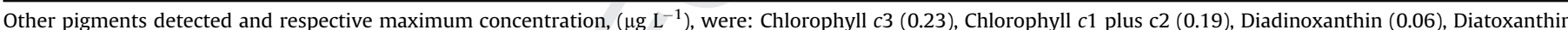
(0.01), Violaxanthin (0.01), Neoxanthin (0.01) and $\beta, \beta$-Caroteno $(0.02)$

$(-)$ means not observed for \% TC and BDL for pigments.

(0.018-0.022 $\mu \mathrm{g} \mathrm{L}^{-1}$ ), where diatoms were more abundant (Table 2, Fig. 4). The second most abundant was Hex-fuco, always present (Table 2), which is in accordance with the ubiquitous presence of coccolithophores, the maximum $\left(0.15 \mu \mathrm{g} \mathrm{L}^{-1}\right)$ corresponded to the highest concentration of $E$. huxleyi, $35 \times 10^{3}$ cell $\mathrm{L}^{-1}$ at \#1, north of Terceira, in spring (Table 2, Fig. 5). Moreover, the highest concentrations of But-fuco and Hex-fuco (characterizing Haptophytes type 6, 7 and 8, Zapata et al., 2004) were coincident, reinforcing the

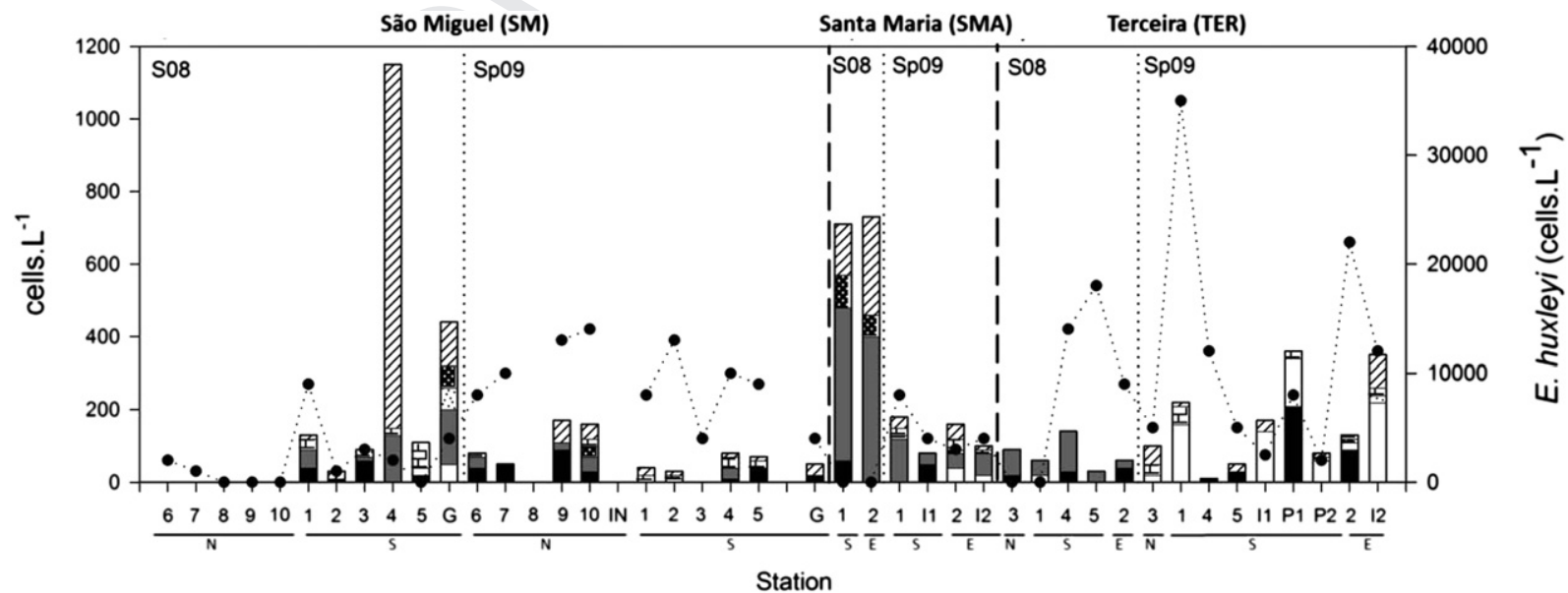

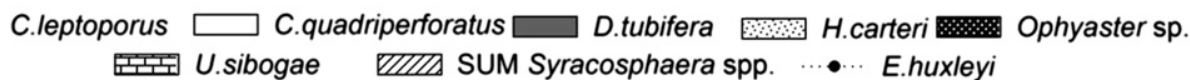

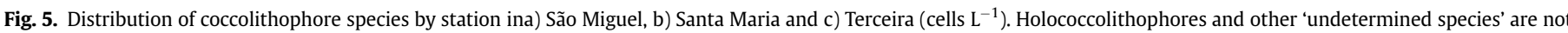
represented here, however its contribution to the total coccolithophore assemblage is shown in Table 2. [N-north, S-south, E-east, S08-summer 2008 and Sp09-spring 2009]. 
observation of the dominance of coccolithophores in the studied area.

The analysis of each of the three islands (Table 2, Fig. 4) showed that around São Miguel (Oriental group), the northern side recorded always higher cell concentrations and the differences in the phytoplankton assemblage from summer 2008 to spring 2009 were: i) coccolithophore cell counts increased on both sides of the island, accounting more than $60 \%$ of TF; ii) diatom maxima changed from $N(\# 6)$ to $S$ (\#5), iii) dinoflagellates declined at the north side, and iv) the small flagellates assemblage increased and were still more abundant on the northern side of the island, dominating the phytoplankton assemblage together with coccolithophores (36\% and $61 \%$ of TF, respectively). The southernmost island of the Oriental group, Santa Maria, showed Chla values in average always extremely low $\left(0.04 \mu \mathrm{g} \mathrm{L}^{-1}\right.$ in summer and $0.16 \mu \mathrm{g} \mathrm{L}^{-1}$ in spring), microscope observations indicated a dominance of coccolithophores ( $>80 \%$ of TF) and the HPLC analysis suggested also the presence of a strong prokaryote community. From summer to spring the diatom assemblage increased while dinoflagellates disappeared. On the other hand, the island from the Central group, Terceira, exhibited the highest Chla concentrations $\left(0.55 \mu \mathrm{g} \mathrm{L}^{-1}\right.$ at the east side, average value \# 2 and $\mathrm{I} 2$, during spring) and cell counts $\left(31.8 \times 10^{3}\right.$ cells $\left.\mathrm{L}^{-1}\right)$. The composition and distribution of phytoplankton groups changed spatially around the island, between summer 2008 and spring 2009 as: i) coccolithophores increased, especially due to higher concentrations of Emiliania huxleyi, and were distributed preferably at the south and east sides of the island, reaching $68 \%$ of TF in the south; ii) diatoms increased at the north ( $68 \%$ of TF) dominating the phytoplankton assemblage, iii) dinoflagellates clearly decreased (from $46 \%$ in the north to $<2 \%$ of TF) and iv) small flagellates decreased to a minor presence $(<4 \% \mathrm{TF})$.
Regarding the distributing of each coccolithophore species (Fig. 5, Table 2), distinct spatial and temporal maxima were observed around each island. E. huxleyi, present in most of the samples, always accounted $>60 \%$ of the total coccolithophore assemblage (TC). The species increased in abundance from summer to spring, except in the south of Terceira. This island and São Miguel recorded the highest concentrations while in Santa Maria, during summer, this species was absent from surface samples. Other identified coccolithophores (Fig. 6), less abundant ( $<47 \%$ of TC) than E. huxleyi, were mostly of a subtropical to temperate origin, as several species from the genus Syracosphaera (grouped as SUM Syracosphaera spp.), Discosphaera tubifera, Calcidiscus leptoporus, Calcidiscus quadriperforatus, Umbilicosphaera sibogae, Helicosphaera carteri and Ophiaster spp. São Miguel and Santa Maria presented a greater number of species and an important contribution of the holoccolithophore fraction (they are produced during the haploid phase of the life-cycle of a wide range of coccolithophores that bear heterococcoliths in their diploid life-cycle phase) to the total coccolithophore assemblage (e.g.83\% of TC in Santa Maria during summer). The Syracosphaera spp. assemblage could not be analysed in the perspective of finding markers for hydrological conditions, since it is composed of several species with a small and random occurrence.

D. tubifera distribution (Table 2, Fig. 5) was higher during summer, at the south of Santa Maria and north of Terceira, but absent during spring conditions around Terceira. The coccolithophores Calcidiscus leptoporus and Calcidiscus quadriperforatus, occurred during both seasons in all islands, with the former being most abundant at the north of Terceira during summer (13.3\% TC) and the latter occurring preferentially during spring around this island in particular. U. sibogae peaked only at the south of São Miguel during summer and was distributed preferably during spring
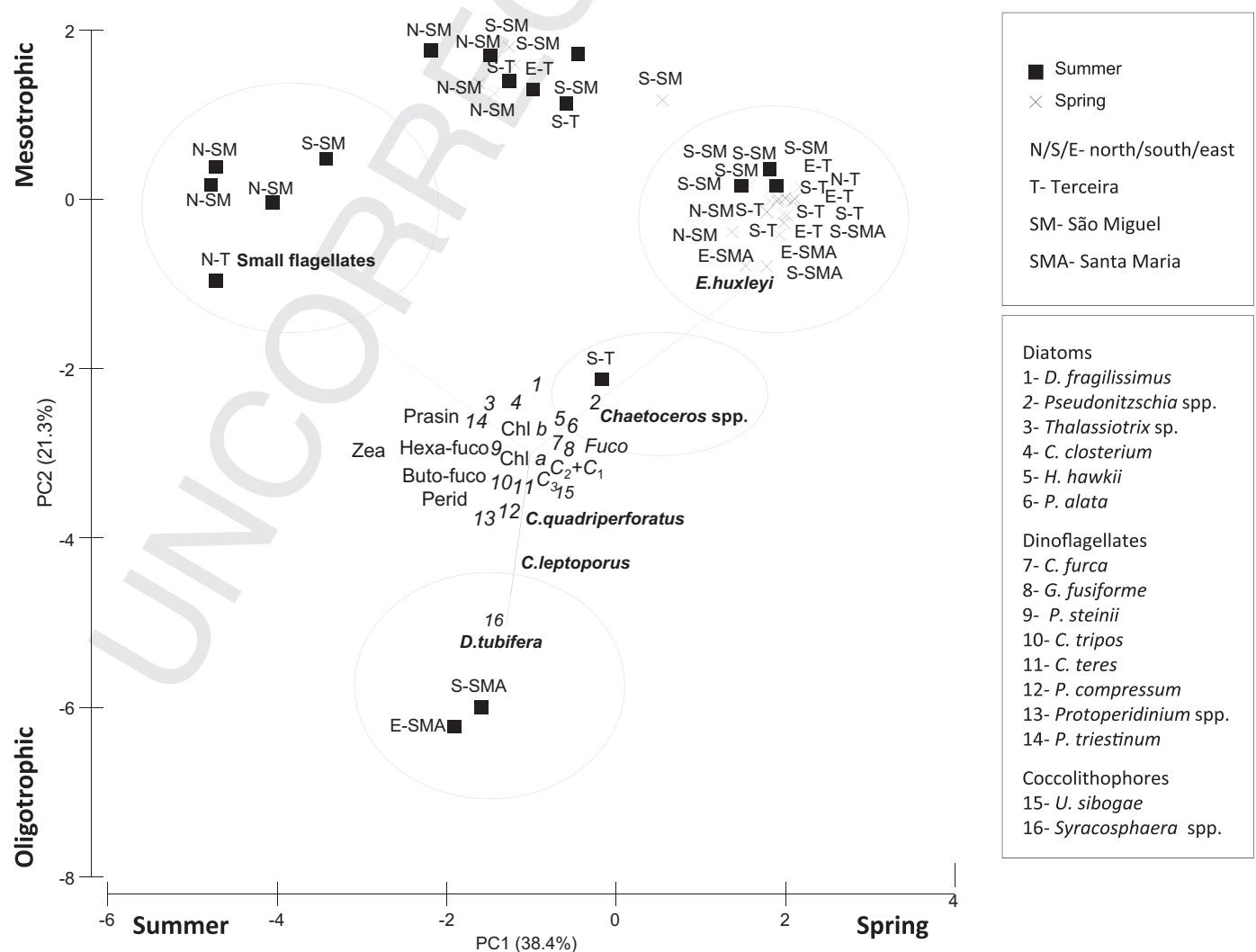

861

Fig. 6. Distribution of phytoplankton species and pigments in the space defined by the first (PC1) and second (PC2) components. 
around Santa Maria and Terceira. Ophiaster species were more abundant during summer in São Miguel and Santa Maria and absent around Terceira.

Concerning the other phytoplankton groups (Fig. 4), diatoms as the chain-forming species from the genera Chaetoceros and Pseudonitzschia were the most abundant, while Guinardia, Dactyliosolen, Leptocylindrus and Thalassiotrix exhibited lower concentrations. These species were recurrent components of diatoms peaks during spring in the south of São Miguel and Santa Maria and during summer in the south of Terceira. The dinoflagellates peaks were mostly composed by the genus Ceratium, Prorocentrum and Protoperidinium as in Terceira during summer (\#3). Unidentified dinoflagellates comprised small thecated as well as naked dinoflagellates but never as a dominant fraction of this phytoplankton component (see Table 3 for all species identified).

\subsection{Principal component analysis}

The first three components explained $79.4 \%$ of the total variation in the data and the first two are represented in Fig. 6 . The first component (PC1) explained $38.4 \%$ of total variability and separated the spring and summer conditions. E. huxleyi was strongly associated with spring while small flagellates appeared related to summer, related to the São Miguel northern stations. The second component (PC2) explained $21.3 \%$ of total variability and separated all stations of São Miguel + small flagellates and Terceira + E. huxleyi from the southernmost island of Santa Maria, during summer, in turn associated with Discosphaera tubifera.
Considering the distinct ecological preferences that these species are known to have from the literature (see Discussion) as well as the observations in this study, this axis was interpreted as a nutrient availability gradient. The third component (PC3, 19.7\%), plot not shown, highlighted a fourth group of species, diatoms Pseudonitzschia spp. and Chaetoceros spp., related to the south station of Terceira during summer (\#1). All the other species and pigments plotted, presented an indistinguishable distribution along axes, with the exception of the two species from the genus Calcidiscus that were slightly detached towards $D$. tubifera.

\section{Discussion}

The complementarity of microscopy observations and HPLC photosynthetic pigment analysis showed that phytoplankton and coccolithophores in particular, the most abundant group, presented temporal differences between summer 2008 and spring 2009, as well as spatial differences in the surface distribution around the three islands (Terceira, São Miguel and Santa Maria). Surface spatial differences between islands appear related to large scale circulation, such as the transport of warm subtropical waters (typically nutrient poor) from the south and colder subpolar waters from the north (see Fig. 2), whereas nearshore small scale differences were associated with the existence of colder water patches representing most probably the signature of upwelling or mixing processes (SSW of Terceira, \# 1-2 and E side of São Miguel, \# 1, Fig. 2). Using satellite and field data, Lafon et al. (2004) observed episodes of lower temperatures and higher chlorophyll concentrations, on the

Table 3

List of the species identified by microscopy.

\begin{tabular}{|c|c|c|c|}
\hline Bacillariophyta (Diatoms) & Dinophyta (Dinoflagellates) & Prorocentrum spp. & Ciliatea \\
\hline Acnanthes spp. & Amphidoma caudatum & Prorocentrum triestinum & Mesodinium rubrum \\
\hline Actinophycus senarius & Ceratium azoricum & Protoperidinium bipes & \\
\hline Bacteriastrum hyalinum & Ceratium candelabrum & Protoperidinium claudicans & \\
\hline Biddulphia spp. & Ceratium falcatum & Protoperidinium crassipes & \\
\hline Chaetoceros spp. & Ceratium furca & Protoperidinium depressum & \\
\hline Cocconeis spp. & Ceratium fusus & Protoperidinium diabolum & \\
\hline Cylindrotheca closterium & Ceratium massiliense & Protoperidinium leonis & \\
\hline Dactyliosolen fragilissimus & Ceratium minimum & Protoperidinium ovum & \\
\hline Detonula pumila & Ceratium pentagonum & Protoperidinium pellucidum & \\
\hline Diploneis spp. & Ceratium teres & Protoperidinium pentagonum & \\
\hline Ditylum brightwellii & Ceratium tripos & Protoperidinium quinquecorne & \\
\hline Grammatophora spp. & Cladopyxis brachiolata & Protoperidinium spp. & \\
\hline Guinardia cf. delicatula & Dinophysis cf. acuminata & Protoperidinium steinii & \\
\hline Guinardia cf. striata & Dinophysis spp. & Protoperidinium tuba & \\
\hline Guinardia flaccida & Diplopsalis spp. & Pseliodinium vaubani & \\
\hline Gyrosigma spp. & Gonyaulax polygramma & Scripsiella cf. trochoidea & \\
\hline Hemiaulus hauckii & Gonyaulax spinifera & Prymnesiophyceae (Coccolithophores) & \\
\hline Hemiaulus sinensis & Gonyaulax spp. & Acanthoica quattrospina & \\
\hline Lauderia annulata & Gymnodinium spp. & Algirosphaera robusta & \\
\hline Leptocylindrus danicus & Gyrodinium fusiforme & Braarudosphaera bigelowii & \\
\hline Leptocylindrus minimus & Gyrodinium spp. & Calcidiscus leptoporus & \\
\hline Licmophora spp. & Lingulodinium polyedrum & Calcidiscus quadriperforatus & \\
\hline Navicula spp. & Noctiluca sintilans & Coronosphaera mediterranea & \\
\hline Nitzschia longissima & Ornithocercus magnificus & Discosphaera tubifera & \\
\hline Paralia sulcata & Ostreopsis cf. ovata & Emiliania huxleyi & \\
\hline Planktionella sol & Ostreopsis cf. siamensis & Gephyrocapsa spp. & \\
\hline Pleurosigma spp. & Ostreopsis heptagona & Helicosphaera carteri & \\
\hline Proboscia alata & Oxytoxum laticeps & Ophiaster spp. & \\
\hline Pseudo-nitzschia spp. & Oxytoxum scolopax & Rhabdosphaera clavigera & \\
\hline Rhizosolenia setigera & Oxytoxum spp. & Syracosphaera prolongata & \\
\hline Rhizosolenia spp. & Phalacroma rotundata & Syracosphaera pulchra & \\
\hline Skeletonema costatum & Podolampas spp. & Syracosphaera spp. & \\
\hline Striatella unipunctata & Pronoctiluca spinifera & Umbilicosphaera sibogae & \\
\hline Surirella spp. & Prorocentrum compressum & Dictyochophyceae (Chrysophyta) & \\
\hline Thalassionema frauenfeldii & Prorocentrum gracile & Dictyocha fibula & \\
\hline Thalassionema nitzschioides & Prorocentrum lima & Prasinophyta & \\
\hline Thalassiosira spp. & Prorocentrum micans & Pterosperma sp. & \\
\hline Thalassiotrix sp. & Prorocentrum scuttelum & Pyramimonas spp. & \\
\hline
\end{tabular}


south coasts of São Miguel and Santa Maria islands, than in offshore waters, proposing the existence of wind-driven upwelling south of these islands.

The satellite imagery (Fig. 2), physical-chemical in situ data, pigment results and species distribution, show clearly that Santa Maria is more strongly influenced by warmer oligotrophic waters from the AC northward incursions, than Terceira and São Miguel. Northward intrusions of warm subtropical water directly in the path of the Santa Maria and São Miguel, and southward intrusions of cold water near Terceira, combine to form a dipole-like structure which enhances gradients in the region. These gradients influenced the distribution of coccolithophore species (Fig. 5, Table 2). Overall results underlined the effect of island-induced biomass enhancement in oligotrophic oceanic regions and the important contribution of the nanoplankton fraction to the pool of Chla instead a picoplankton dominated assemblage. This shift is particularly evident at all islands during spring, when zeaxanthin is absent (Table 2). The average and standard deviation Chla values obtained in the present paper were: Terceira: $0.37 \pm 0.22$, São Miguel $0.27 \pm 0.08$ and Santa Maria $0.11 \pm 0.04 \mu \mathrm{g} \mathrm{l^{-1 }}$. Except for Santa Maria island, these values are much higher than those reported by Aiken et al. (2009), in a decadal study for the same latitudes in the NAST-E region $\left(<0.25 \mu \mathrm{g} \mathrm{l}^{-1}\right)$, where phytoplankton is dominated by prokaryotes and picoflagellates. In accordance with the spatial and temporal pattern for phytoplankton, surface nutrient results showed enrichment during spring more noticeable around Terceira (most influenced by colder subpolar waters). The values obtained in spring are similar to the ones found by Schiebel et al. (2011) for a $\mathrm{N}-\mathrm{S}$ transect along $20^{\circ} \mathrm{W}\left(33^{\circ} 00.039^{\prime} \mathrm{N}-46^{\circ} 59.607^{\prime} \mathrm{N}\right)$ in the North Atlantic. The relative abundance of silicates in relation to the other nutrients registered in this study was also observed by these authors. The fact that values reported here are, in some cases, double might be explained by the vicinity to the coast and the volcanic nature of these islands.

During summer, the coccolithophore assemblage (Fig. 6, Table 2) was mainly composed by umbelliform species (k-selected), as Discosphaera tubifera, in contrast with the dominance of placolithbearing species during spring, as Emiliania huxleyi (r-selected). Young (1994) defined three ecological communities of coccolithophores associated with three distinct environments: i) placolithbearing cells such as E. huxleyi, Gephyrocapsa, Calcidiscus, found in coastal or mid-ocean upwelling regions; ii) umbelliform cells such as D. tubifera, Rhabdosphaera clavigera and Umbilicosphaera sibogae, found in more oligotrophic and calm waters and iii) floriform cells, such as Florisphaera profunda, associated with deep photic-zone assemblages.

In the present work, the subtropical coccolithophore assemblage comprising the umbelliform Discosphaera tubifera, detached by the PCA analysis, indicates the influence of surface warmer waters of the Azores current (AC) around the islands, as well as summer conditions of reduced mixing and low nutrient concentration. This is particularly noticeable during summer, around Santa Maria (21.9\% TC) and at the northern side of Terceira (46.7\% TC). The coastal/upwelling related species Emiliania huxleyi was absent from these samples in both islands (Table 2, Fig. 5). D. tubifera has been associated with warm waters (in this study, $22.6{ }^{\circ} \mathrm{C}$, the highest temperature) depleted in nitrate and having a preference for very high light intensities by Haidar and Thierstein (2001) around Bermuda. We should emphasize that the highest abundance of D. tubifera coincided with the absence of nitrates in surface waters. D. tubifera maximum was also coincident with Calcidiscus leptoporus maximum concentration in the north of Terceira during summer (13.3\%TC, $22.6{ }^{\circ} \mathrm{C}$, and absence of nitrates). This coccolithophore is usually observed in oceanic warm stratified and nutrient depleted conditions in the $\mathrm{N}$ Atlantic (e.g. Haidar and
Thierstein, 2001; in Bermuda, Renaud et al., 2002; in NABE-48, Silva et al., 2009; in Lisbon bay). In the genus Calcidiscus, Calcidiscus quadriperforatus presence coincided with higher nitrate and Chla averages, most evident at the east side of Terceira during spring $\left(0.7 \% \mathrm{TC}, \quad 17.4{ }^{\circ} \mathrm{C}\right)$, where the highest biomass (Chla $\left.=0.55 \mu \mathrm{g} \mathrm{L}^{-1}\right)$ and nitrate $(1.39 \mu \mathrm{M})$ concentrations were observed (mean values for stations 2 and I2). This species is considered to be more opportunistic than C. leptoporus (e.g. Haidar and Thierstein, 2001; in Bermuda, Renaud et al., 2002; in NABE-48, Silva et al., 2009; in Lisbon bay). In the genus Calcidiscus, C. quadriperforatus is considered to be more suitable to emphasise the onset of the spring bloom or more productive environments, opposite to D. tubifera and C. leptoporus.

The larger concentrations of holococcolithophores in Santa Maria (83\% TC in the south) and Terceira (26.7\% TC in the north) during summer, which were mainly due to Discosphaera tubifera and $C$. leptoporus, also confirm these species as indicators of warm oligothophic conditions. Several authors (e.g Kleijne, 1991; Brand, 1994; Renaud and Klaas, 2001; Haidar and Thierstein, 2001) found more frequently the fragile haploid phase of coccolithophores in oligotrophic waters, higher temperatures and light intensities or associated with the beginning of water stratification and subsequent nutrients depletion.

Conversely, and as demonstrated by the PCA results, the greater development of diatoms and placolith-bearing Emiliania huxleyi during spring suggested a change in the hydrological regime towards more eutrophic conditions. E. huxleyi is considered to have an opportunistic behaviour usually reported during the early stage of phytoplankton spring production (Schiebel et al., 2011 for the North Atlantic, Silva et al., 2008 for Lisbon Bay). During summer the colder water patches observed (\# 1-2 in Terceira, \# 1 in São MIguel) were dominated by E. huxleyi and diatoms (e.g. chain forming Chaetoceros spp.) illustrating the enhancement effect of these colder patches on phytoplankton biomass. The boundaries of these patches were characterized by subtropical coccolithophores, like Discosphaera tubifera, and dinoflagellates (Fig. 5, Table 2). Dinoflagellates were in most stations the less abundant phytoplankton group with a surface distribution similar to the subtropical assemblage of coccolithophores, indicating stratified and intermediate to oligotrophic conditions (Fig. 4, Table 2). The greater abundances, in the north of Terceira during summer coincided with the higher concentrations of the subtropical $D$. tubifera.

The present findings seem to indicate that coccolithophore species could have a role in the study of the surface circulation patterns and hydrological variability around the Azores archipelago and that they are an important contribution to the pool of Chla, especially during spring. This work has contributed to the knowledge on the phytoplankton component of this biogeochemical ocean province which is still rather limited.

\section{Uncited reference}

Jeffrey and Hallegraeff, 1987.

\section{Acknowledgements}

Field work was supported by the Projects "Caracterização das massas de água costeiras (CAMAG) das ilhas do grupo oriental (ORI) e Terceira (TER)" funded by Direcção Regional do Ordenamento do Território e Recursos Hídricos. The surveys performed in the present study comply with the current laws of Portugal. We thank Steve Groom, from Plymouth Marine Laboratory, for reading and commenting the manuscript. This work was partly funded by PEstOE/MAR/UI0199/2011 (FCT), Projecto Estratégico - Centro de Oceanografia (CO/FC/UL) - 2011-2012, and by the ESA CoastColour 
Project. Vanda Brotas had a sabbatical grant from FCT (SFRH/BSAB/ 1044/2010). We also thank the anonymous referees who commented the manuscript.

\section{References}

Aiken, J., Pradhan, Y., Barlow, R., Lavender, S., Poulton, A., Holligan, P., HardmanMountford, N., 2009. Phytoplankton pigments and functional types in the Atlantic Ocean: a decadal assessment, 1995-2005. Journal of Deep-Sea Research II 56, 899-917.

Andruleit, H., 2007. Status of the Java upwelling area (Indian Ocean) during the oligothrophic northern hemisphere winter monsoon season as revealed by coccolithophores. Marine Micropaleontology 64 (1-2), 36-51.

Bakker, D.C.E., Nielsdóttir, M.C., Morris, P.J., Venables, H.J., Watson, A.J., 2007. The island mass effect and biological carbon uptake for the subantarctic Crozet Archipelago. Deep Sea Research II 54, 2174-2190.

Beaufort, L., Heussner, S., 2001. Seasonal dynamics of calcareous nannoplankton on a West European continental margin: the Bay of Biscay. Marine Micropaleontology $43(1-2), 27-55$.

Beaufort, L., Couapel, M., Buchet, N., Claustre, H., Goyet, C., 2008. Calcite production by coccolithophores in the south east Pacific Ocean. Biogeosciences 5, 11011117. http://dx.doi.org/10.5194/bg-5-1101-2008.

Bollmann, J., Cortés, M.Y., Haidar, A.T., Brabec, B., Close, A., Hofmann, R., Palma, S., Tupas, L., Thierstein, H.R., 2002. Techniques for quantitative analyses of calcareous marine phytoplankton. Marine Micropaleontology 44, 163-185.

Brand, L.E., 1994. Physiological ecology of marine coccolithophores. In: Winter, A., Siesser, W.G. (Eds.), Coccolithophores. Cambridge University Press, UK, pp. 39-49.

Broerse, A.T.C., Ziveri, P., van Hinte, J.E., Honjo, S., 2000. Coccolithophore export production, species composition, and coccolith- $\mathrm{CaCO}_{3}$ fluxes in the NE Atlantic ( $34^{\circ} \mathrm{N} 21^{\circ} \mathrm{W}$ and $48^{\circ} \mathrm{N} 21^{\circ} \mathrm{W}$ ). Deep-Sea Research II 47, 1877-1905.

Brotas, V., Plante-Cuny, M.R., 1996. Identification et quantification des pigments chlorophylliens et caroténoïdes des sédiments marins. Choix dun protocole danalyse par HPLC. Oceanologica Acta 19 (6), 623-633.

Clarke, K.R., Gorley, R.N., 2006. Primer - Plymouth Routines in Multivariate Ecological Research - v6: User Manual/Tutorial. PRIMER-E Ltd, Plymouth, U.K, p. 192

CLS (Collecte Localisation Satellites), 2009. SSALTO/DUACS User Handbook: (M)SLA and (M)ADT Near-Real Time and Delayed Time Products. Ref. CLS-DOS-NT06.034. Available from: http://www.aviso.oceanobs.com/fileadmin/ documents/data/tools/hdbk_duacs.pdf.

CMS (Centre de Météorologie Spatiale), 2009. Low Earth Orbiter Sea Surface Temperature Product User Manual. Ref. SAF/OSI/CDOP/M-F/TEC/MA/127 Available from: http://www.osi-saf.org/biblio/docs/ss1_pum_leo_sst_2_1.pdf

Dodge, J.D., 1982. Marine Dinoflagellates of the British Isles. Her Majesty's Stationary Office, London.

Fanning, K.A., Pilson, M.E.Q., 1973. On the spectrophotometric determination of dissolved silica in natural waters. Analytical Chemistry 45, 136-141.

Gould, W.J., 1985. Physical oceanography of the Azores Front. Progress in Oceanography 14, 167-190.

Grassoff, K., 1976. Methods of Seawater Analysis. Verlag Chimie, New York, 520 p.

Haidar, A.T., Thierstein, H.R., 2001. Coccolithophore dynamics off Bermuda (N. Atlantic). Deep Sea Research II 48 (8-9), 1925-1956.

Hair Jr., J.F., Anderson, R.E., Tatham, R.L., Black, W.C., 1998. Multivariate Data Analysis, fifth ed. Prentice Hall, Upper Saddle River, NJ: USA.

Hasegawa, D., Yamazaki, H., Ishimaru, T., Nagashima, H., Koike, Y., 2008. Apparent phytoplankton bloom due to island mass effect. Journal of Marine Systems 69, 238-246.

Hasle, G.R., 1978. Phytoplankton manual: the inverted microscope method. In: Sournia, A. (Ed.), Monographs on Oceanic Methodology. Unesco, Paris, pp. 88-96.

Hasle, G.R., Syvertsen, E.E., 1996. Marine diatoms. In: Tomas, C.R. (Ed.), Identifying Marine Diatoms and Dinoflagellates. Academic Press, Inc., London, pp. 5-385.

Holligan, P.M., Fernandez, E., Aiken, J., Balch, W.M., Boyd, P., Burkill, P.H., Finch, M., Groom, S.B., Malin, G., Muller, K., Purdie, D.A., Robinson, C., Trees, C.C., Turner, S.M., Van der Wal, P., 1993. A biogeochemical study of the coccolithophore, Emiliania-huxleyi, in the North-Atlantic. Global Biogeochemical Cycles 7, 879-900.
Jeffrey, S.W., Hallegraeff, G.M., 1987. Phytoplankton pigment, species and light climate in a complex warm-core eddy of the east Australian Current. Deep Sea Research I 34 (5-6), 649-673.

Jeffrey, S.W., Mantoura, R.F.C., Bjørnland, T., 1997. Data for the identification of 47 key phytoplankton pigments. In: Jeffrey, S.W., Mantoura, R.F.C., Wright, S.W. (Eds.), Phytoplankton Pigments in Oceanography: Guidelines to Modern Methods. Unesco Monographs on Oceanographic Methodology, vol 10. UNESCO, Paris, pp. 449-559.

Juliano, M.F., Alves, M.L.G.R., 2007. The Atlantic subtropical Front/Current systems of Azores and St. Helena. Journal of Physical Oceanography 37, 2573-2598.

Kleijne, A., 1991. Holococcolithophores from the Indian ocean, red sea, Mediterranean sea and north Atlantic ocean. Marine Micropaleontology 17, 1-76.

Kraay, G.W., Zapata, M., Veldhuis, M.J., 1992. Separation of chlorophylls c1, c2, and c3 of marine phytoplankton by reversed-phase-C18-High-Performance Liquid Chromatography. Journal of Phycology 28, 708-712.

Lafon, V., Martins, A., Bashmachnikov, I., Jose, F., Melo-Rodriguez, M., Figueiredo, M., Mendonça, A., Macedo, L., 2004. SST variability in the Azores region using AVHRR imagery: regional to local scale study. In: Remote Sensing of Ocean and Sea Ice, Vol. 5569, pp. 130-139. Proceedings of SPIE Vol. 5569, 130-139.

Longhurst, A., Sathyendranat, S., Platt, T., Caverhill, C., 1995. An estimate of global primary production in the ocean from satellite radiometer data. Journal of Plankton Research 17, 1245-1271.

Mendes, C.R., Cartaxana, P., Brotas, V., 2007. HPLC determination of phytoplankton and microphytobenthos pigments: comparing resolution and sensitivity of a C18 and a C8 method. Limnology Oceanography Methods 5, 363-370.

Murphy, J., Riley, J.P., 1962. A modified single solution method for the determination of phosphate in natural waters. Analytica Chimica Acta 27, 31-36.

Renaud, S., Klaas, C., 2001. Seasonal variations in the morphology of the coccolithophore Calcidiscus leptoporus off Bermuda (N. Atlantic). Journal of Plankton Research 23, 779-795.

Renaud, S., Ziveri, P., Broerse, T.C., 2002. Geographical and seasonal differences in morphology and dynamics of the coccolithophore Calcidiscus leptoporus. Marine Micropaleontology 46, 363-385.

Rost, B., Riebesel, 1, U., Burkhardt, S., Sültemeyer, D., 2003. Carbon acquisition of bloom forming marine phytoplankton. Limnology and Oceanography 48 (1), 55-67.

Schiebel, R., Brupbacher, U., Schmidtko, S., Nausch, G., Waniek, J.J., Thierstein, H.-R., 2011. Spring coccolithophore production and dispersion in the temperate eastern North Atlantic Ocean. Journal of Geophysical Research 116, C08030. http://dx.doi.org/10.1029/2010JC006841.

Smyth, T.J. Tyrrell, T., Tarrant, B., 2004. Time series of coccolithophore activity in the Barents Sea from twenty years of satellite imagery. Geophysical Research Letters 31, L11302. http://dx.doi.org/10.1029/2004GL019735.

Silva, A., Palma, S., Moita, M.T., 2008. Coccolithophores in the upwelling waters of Portugal: four years of weekly distribution in Lisbon Bay. Continental Shelf Research 28, 2601-2613.

Silva, A., Palma, S., Oliveira, P.B., Moita, M.T., 2009. Calcidiscus quadriperforatus and Calcidiscus leptoporus as oceanographic tracers in Lisbon bay (Portugal). Estuarine Coastal and Shelf Science 81, 333-344.

Sprengel, C., Baumann, K.-H., Neuer, S., 2000. Seasonal and interannual variation of coccolithophore fluxes and species composition in sediment traps north of Gran Canaria (29oN 15oW). Marine Micropaleontology 39 (1-4), 157-178.

Tortell, P.D., Giocoma, R.D., Sigman, D.M., Morel, F.M.M., 2002. $\mathrm{CO}_{2}$ effects on taxonomic composition and nutrient utilization in an Equatorial Pacific phytoplankton assemblage. Marine Ecology Progress Series 236, 37-43.

Tyrrell, T., 2008. Calcium carbonate cycling in future oceans and its influence on future climates. Journal of Plankton Research 30 (2), 141-156.

Throndsen, J., 1978. Phytoplankton manual: preservation and storage. In: Sournia, A. (Ed.), Monographs on Oceanic Methodology. Unesco, Paris, pp. 69-75.

Young, J., Geisen, M., Cros, L., Kleijne, A., Sprengel, C., Probert, I., Ostergaard, J., 2003. A guide to extant coccolithophore taxonomy (special issue 1). Journal Nannoplankton Research, 123

Young, J., 1994. Function of coccoliths. In: Winter, A., Siesser, W.G. (Eds.), Coccolithophores. Cambridge University Press, Cambridge, pp. 63-82.

Zapata, M., Jeffrey, M., Wright, S.W., Rodríguez, F., Garrido, J.L., Clementson, L., 2004 Photosynthetic pigments in 37 species (65 strains) of Haptophyta: implications for oceanography and chemotaxonomy. Marine Ecology Progress 270, 83-102. 